\title{
理系女性研究者の活躍に向けて 一東京農工大学における女性研究者支援の取組
}

\author{
宮浦千里
}

\section{はじめに}

わが国における女性研究者比率は、欧米諸国 と比べて著しく低く、女性研究者がその能力を 最大限に発揮できるようにするため、研究と出 産・育児等の両立に配慮した措置を拡充するこ と、そして女性研究者の採用を促進することが 求められている。内閣府男女共同参画推進本部 は、平成 15 年 6 月、社会のあらゆる分野にお いて、2020年までに指導的地位に女性が占め る割合を少なくとも $30 \%$ 程度とする「2020年 $30 \% 」$ の目標を掲げ、さらに平成 27 年 8 月に女 性管理職の割合に数值目標を義務づける「女性 活躍推進法」が可決・成 立、平成 28 年 4 月に施行 された。

近年、様々な取組によ り、女性研究者の割合は 上昇傾向にあるものの、 $15.3 \%$ （平成 28 年 3 月 31 日現在）にとどまってお り、諸外国と比べるとそ の割合は低い（出展「平 成 29 年版男女共同参画白 書科学技術の進展と男女 共同参画」)。また、専門 分野別に見た大学等の研 究本務者における女性の
比率は、薬学・看護等の分野では $51.8 \%$ と女性 が半数以上を占める一方、社会科学、医学・歯 学などは $30 \% に$ に満たず、工学は $10.2 \%$ 、理学は $14.2 \%$ にどまっており、その傾向は理工系分 野で顕著である（出展：総務省「科学技術研究 調査」(平成 28 年))。その背景には、女子学生 が進学先や職業として理工系分野を選ばない割 合が大きく、その要因の一つには、理科の成績 や進路に関する教師や両親など、周囲の意識が 影響していることがあげられる(文部科学省「学 校教育におけるジェンダー・バイアスに関する 研究」)。

東京農工大学は、先進的研究力を重視した農

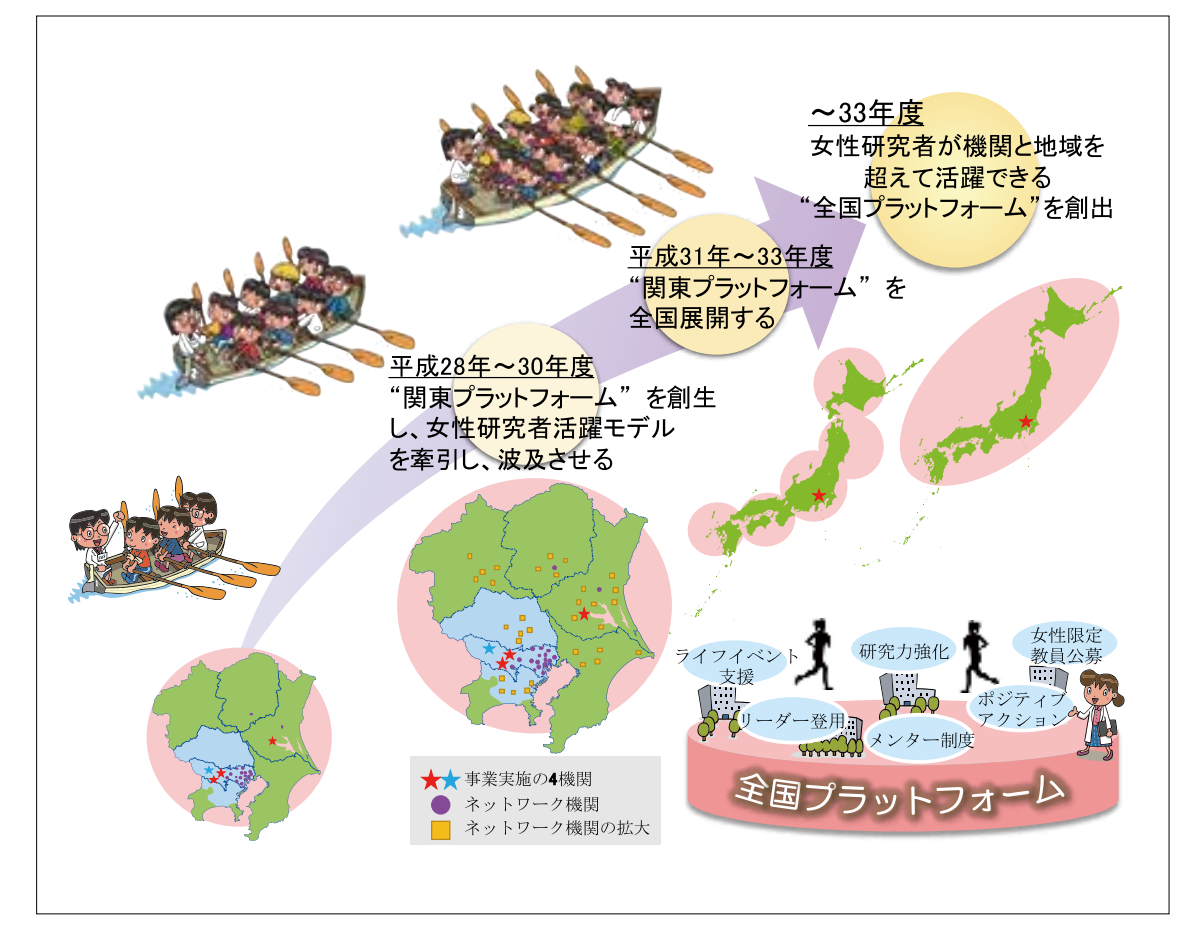

図1 “関東プラットフォーム”創生と“全国プラットフォーム”への展開 
学と工学からなる大学院大学であり、中規模理 系大学に扔ける女性研究者活躍支援の先駆的取 組を行ってきた。本学では、平成 18 年度の女 性研究者支援モデル育成事業「理系女性のエン パワーメントプログラム」の採択を受け、同 年9月1日、事業の中核組織である女性キャリ ア支援・開発センターを新設し、全学的な女 性研究者支援事業を開始した。この事業が平成 21 年 3 月に終了することを受け、平成 21 年 2 月 に、女性キャリア支援・開発センターを発展的 に改組して、女性未来育成機構を新たに設置し た。その後、女性研究者養成システム改革加速 事業「理系女性のキャリア加速プログラム」(平 成 $21 \sim 25$ 年)、女性研究者研究活動支援事業(拠 点型）「理系女性のキャリア支援ネットワーク の形成〜拡げます農工大式支援ノウハウ〜」(平 成 $25 \sim 28$ 年) を受け、女性未来育成機構が中 心となって女性研究者の研究支援環境整備およ び養成、採用促進に取組んできた。そして、平 成 28 年度ダイバーシティ研究環境実現イニシ アティブ (斢引型)「女性研究者の活躍推進を 実現する“関東プラットフォーム”の創生と全 国展開」の採択を受け、代表機関である東京農 工大学と共同実施機関の東京外国語大学、国際 農林水産業研究センター、首都圈産業活性化協 会が連携し、女性研究者の上位職への積極登用 に向けた取組を関東の様々な機関に拡げ、全国 展開を目指した取組を行っている（図1）。本 稿では、本学の女性研究者支援の取組内容およ び「女性研究者の活躍推進を実現する“関東プ ラットフォーム”の創生と全国展開」について

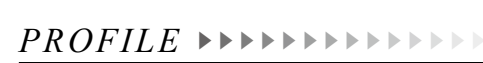

宮浦千里 (みゃうら ちさと)

“東京農工大学副学長·女性未来育成機構長. 教授

專門 骨代謝学、病態生化学

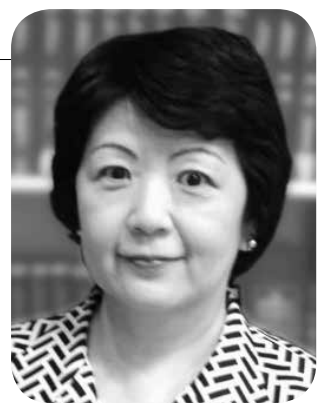

紹介したい。

\section{女性研究者支援の取組}

本学では 1) 女子学生対象のキャリアパス支 援、2）女性研究者対象の出産・育児・介護支 援システム、3）女性卒業生のネットワーク構 築、4）大学のエンパワーメント環境整備、の 四つの事業を軸に男女共同参画に関わる大学シ ステム改革を実施している。各事業内容につい て以下に紹介する。

\section{1）キャリアパス支援}

主な取組として、女子大学院生が女子学生の 研究生活、進路に関する相談に応じる「メンター 制度」の施行、学内外の研究者を講師として招 聘し、研究紹介やワークライフバランスなどを テーマにした「キャリアセミナー」の開催、女 子中高生の理系進路選択支援を目的とした「サ マースクール」の開催などが挙げられる。これ らの一連の取組は、女子学生が理系分野への進 学および就職を積極的に選択できるよう促すこ とを目的として実施している。

\section{2）出産・育児・介護支援システム}

出産・育児・介護期にある女性研究者の研究 停滞を防ぐことを目的とし、女性研究者（女性 の教員 - 博士研究員 - 博士後期課程大学院生) 


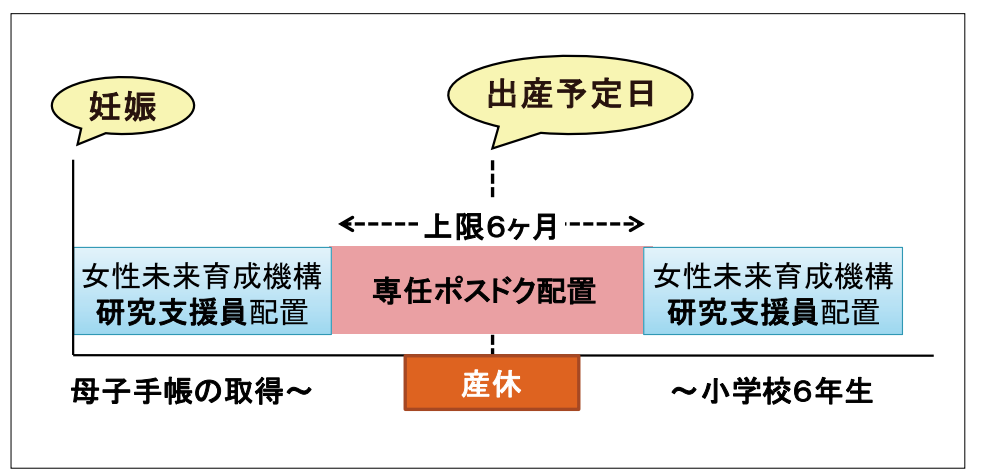

図2 出産・育児期の研究サポートシステムの体制図
報を提供するためのイベントを、随 時開催している。

\section{4）エンパワーメント環境整備}

男女共同参画に関する教職員の意 識改革を推進するために、シンポジ ウム開催、学長と女性教員との意見 交換会や、意識改革講演会等を定期 的に開催している。また、ンパワー を対象に研究支援員を週 1 ～2回派遣する学内 研究サポートシステムを実施している。さらに、 産休取得期間にある常勤教員に対しては、専任 の産休ポスドクを大学経費にて雇用し、6ヶ月 を上限に配置する制度も実施している（図2）。

また、保健師、助産師の資格を持つ本学女性 卒業生を相談員とする、出産・育児・介護相談 空口の設置、病時病後児保育や介護サービスの 割引が受けられる支援制度も行っている。

\section{3）女性卒業生のネットワーク構築}

女性卒業生同士のコミュニティー、育児、再 就職や復学に関する情報提供の場として女性卒 業生限定の農工大SNS（ソーシャル・ネット ワーキング・サービス）を運用している。ま た、本学卒業生が研究生および科目等履修生と して入学した場合、学費を減免する制度を設け た。学費減免率は、入学金は $100 \%$ 、授業料は 50\%である。これにより、女性卒業生の大学院 への入学など再チャレンジへの支援を実施して いる。その他、卒業生のブラッシュアップに向 けての具体的なニーズ把握や、復学に関する情 メント環境整備を進めるにあたり、意識改革ア ンケートを適宜実施し、男女共同参画と環境整 備のニーズを把握し、取組に優先順位をつけて 実施に生かしている。それらを踏まえて、育児 休業、部分休業、看護休㗇、休業取得要件等、 規程改定や、学内保育所の設置など、環境整備 を進めてきた。

\section{農工大式ポジティブアクション「1プラス1 (ワン・プラス・ワン)」による女性研究者 の採用}

本学における女性研究者の雇用促進と学内の 男女共同参画の推進を目的として、平成 21 年 4 月より、本学独自のポジティブアクション「1

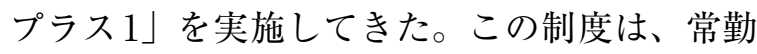
の教授・准教授・講師・助教に女性を採用した 場合、当該専攻等にプラス 1 名分の特任助教の 人件費を学長裁量経費から支給する制度であ り、採用した女性教員の職階を基準に、毎年度 2 名の支給対象を決定するという農工大式の取 組である。本制度を活用しながら、女性教員の 新規採用を強力に進めて、女性教員倍増計画を 
実現している。また、この女性研究者採用シス テムは、ダイバーシティ研究環境実現イニシア ティブ (牽引型) 事業における女性幹部登用ポ ジティブアクション「1プラス $1 」$ の発展への 礎となっている。

\section{ダイバーシティ研究環境実現イニシア ティブ(牽引型)事業「女性研究者の活躍 推進を実現する“関東プラットフォーム” の創生と全国展開」}

文部科学省科学技術人材育成費補助事業「ダ イバーシティ研究環境実現イニシアティブ（牽 引型)」は、研究環境のダイバーシティを高め、 優れた研究成果の創出につなげるため、各機関・
地域の特色を踏まえた目標・行動計画を設定・ 公表することを要件とし、女性研究者の研究環 境の整備や研究力向上のための取組および女性 研究者の積極採用や上位職への積極登用につな げていくことを目的としている。本学で実施し ている取組概要は以下の通りである。

\section{1）実施体制}

女性未来育成機構は、キャリア支援部門（支 援と環境整備)、キャリア加速部門（教育プロ グラム)、キャリア開発部門（研究プログラム）、 広域ネットワーク形成部門の 4 部門で構成され ている（図3）。以下に、各部門の役割につい て紹介する。共同実施機関は、東京外国語大学、

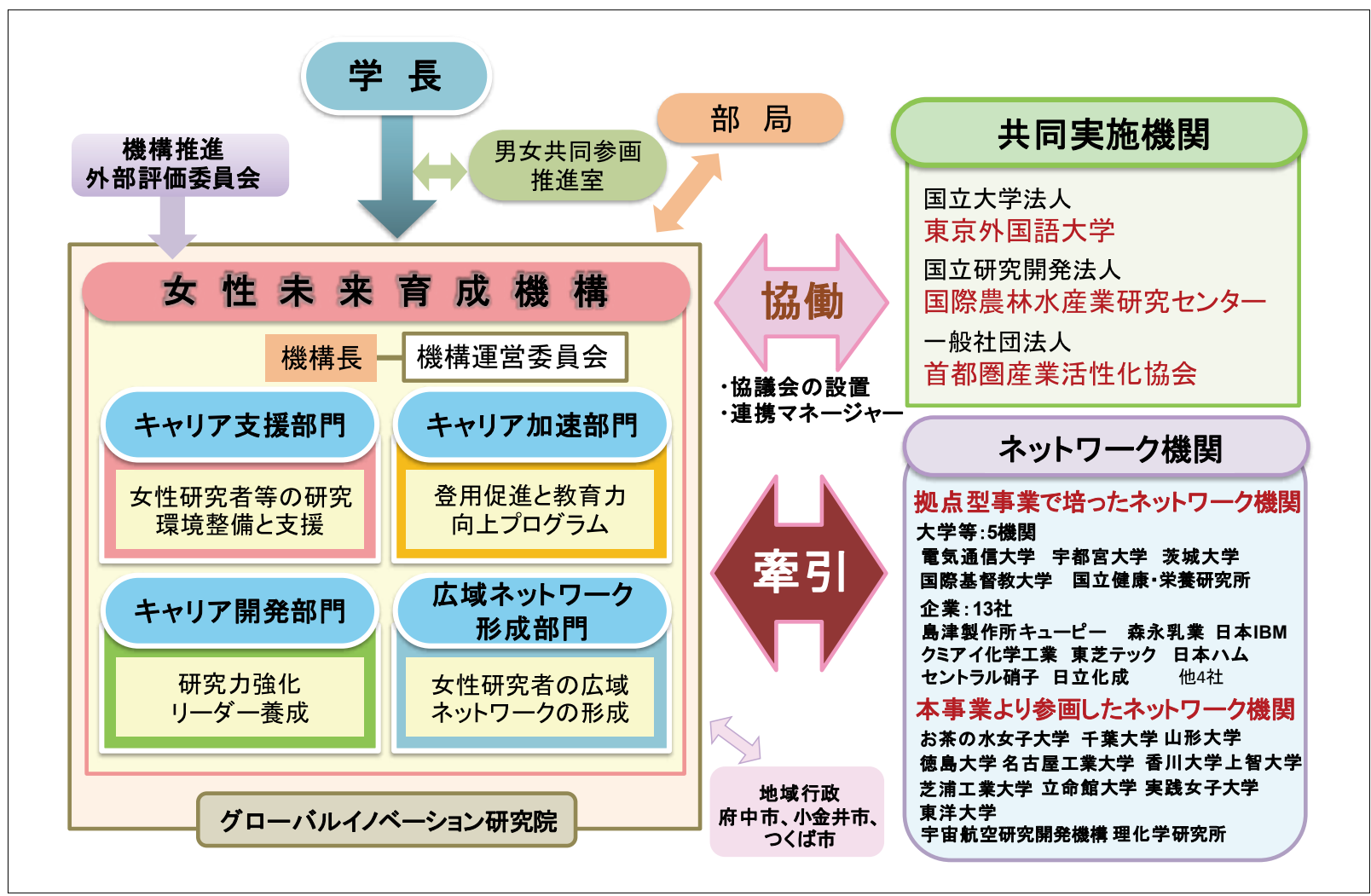

図3「理系女性のキャリア加速プログラム」の運営体制 
国際農林水産業研究センター、首都圈産業活性 化協会である。さらに、ネットワーク機関とし て、30機関以上が参画している。

\section{キャリア支援部門}

「理系女性のキャリア支援ネットワークの形 成〜拡げます農工大式支援ノウハウ〜」の事業 内容を継承し、主に女性研究者の支援と環境整 備を行っている。学内保育所は 2 施設開所して おり、NPO等により運営されている。

\section{キャリア加速部門}

女性研究者の登用促進と教育力向上プログラ ムを実施する部門である。教育力向上プログ ラムとは、学部および大学院教育をプラット フォームとし、実践講義·実習指導を実施して、 独創性・即応性・持久性を習得するプログラム である。教員として活躍するには研究実施のみ ならず、研究費申請、学生指導、各種委員会活 動、学会等の学外活動など、多様な活動が必要 である。メンター教員を学内に配置するのみな らず、ネットワーク機関との間でグループメン ター制度を構築して、広く相互の相談を可能と し、ロールモデルの共有も目指している。

\section{キャリア開発部門}

女性研究者の研究力強化とリーダー養成のた めのプログラムを実施する部門である。これま でに、ネットワーク機関と女性研究者の研究力 向上とリーダー育成に関わる取組進渉状況の共 有を図ってきた。本学の女性教員が共同実施機
関（東京外国語大学、国際農林水産業研究セン 夕ー）の女性研究者と共同して、海外機関研究 者を含む国際共同研究を実施している。さらに、 国際研究力および国際発信力の強化を目的とし て、合同発表・評価会も実施している。これら 取組により、既成概念の枠を超えた発想と課題 提案型の立案力・国際研究力を兼ね備えた女性 研究者の養成を目指している。

\section{広域ネットワーク形成部門}

「理系女性のキャリア支援ネットワークの形 成〜拡げます農工大式支援ノウハウ〜」の拠点 型事業では、大学等 5 機関および企業 13 社との 協力体制を構築して、事業終了時には提言を公 表した。その内容を継承し、現在実施している、 牽引型事業では、関東におけるネットワーク形 成を推進しており、全国展開を視野に入れて遠 隔地機関との連携も構築しつつある。

\section{2）本プログラムの実施状況および期待される} 効果

\section{女性研究者の上位職登用に向けた取組}

女性研究者ネットワークの拡大に向けた取組 を実施している。本事業開始より、13機関が 新たにネットワーク機関に参画している（平成 29 年 6 月現在)。また、女性リーダーの育成と 女性管理職の増加を図るため、本学独自の“女 性幹部登用ポジティブアクション「1プラス $1 」 ”$ を機関自主経費により実施するための制度を構 築する予定である。この採用システムを運用す ることで、女性幹部登用を推進するシステムを 


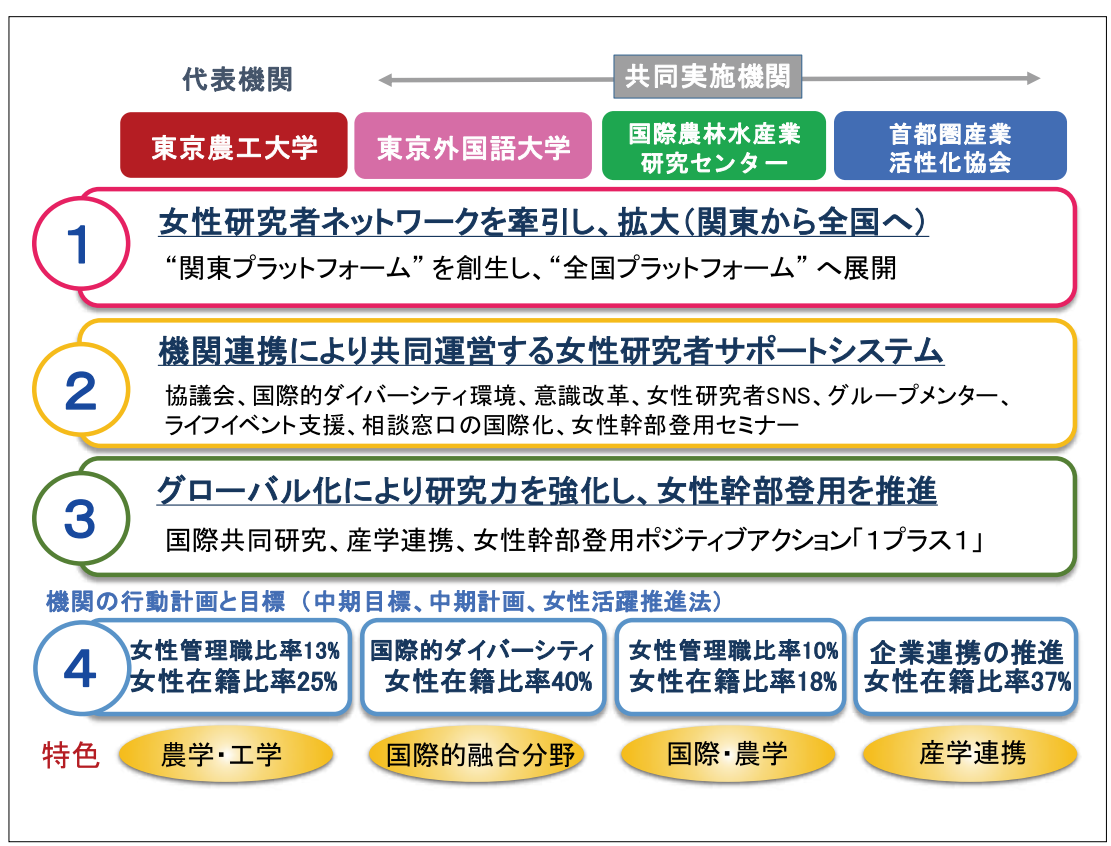

図4 取組内容の概要

学内に浸透させる効果が期待され、女性研究者 の採用と活用の推進につながると考えられる (図4)。

本学では、平成 21 年〜平成 24 年の間におい て、新規に採用された常勤教員の女性研究者採 用比率は累計で $31.4 \%$ に達し、採用数も計画を 大幅に超える23名を新規採用した。この結果 から、独自努力である農工大式ポジティブアク ション「1プラス $1 」$ を含めた女性研究者増加 に向けた取組が、非常に高い相互効果を持つこ とが明らかとなった。全国的に女性割合が最も 低い工学や農学の研究分野において、女性教員 数の倍増を実現したシステム改革はこれまでに なく、他に類をみない成果となっている。本事 業において女性幹部登用のためのシステムを構 築し、農学・工学系の女性教員の在籍比率を $25 \%$ 以上、女性管理職比率 $13 \%$ 達成を目指す
計画である。

\section{女性研究者の育成}

女性未来育成機構の 4 部 門における、(1)支援と環境 整備、(2)登用促進と教育力 向上プログラム、(3)研究力 向上プログラムの実践、(4) 女性研究者の広域ネット ワークの形成によって、出 産・育児による研究停滞が なく、独創性・即応性・持 久性に秀でた優秀な女性研 究者を育成する。この養成 システムにより、女性研究者数の増加のみなら ず女性研究者の質の向上に組織的に取組むこと が可能となる。

理系中規模大学である本学において実施する これらの取組は、女性の進出が遅れている農学 や工学系において女性研究者を加速的に増や し、質の高い女性研究者をいかに養成するかに ついて、他機関に提示する先駆的モデルとなり、 大きな波及効果が期待できる。

\section{おわりに}

女性研究者や研究職を目指す女性は、研究者 としての成果を示さなければならない一方で、 出産・育児・介護と研究との両立などの問題を 抱えている。また近年、子どもの理系離れが深 刻化しており、特に女子の理系進路選択が少な 
いことが問題視されている。これらの背景より、 女性研究者が少ない農学、工学の分野において、 理系分野を活性化し、ロールモデルを増加させ、 女性研究者がその能力を十分に発揮しながら、 ワークライフバランスを維持していける環境づ くりや支援が求められている。東京農工大学で は、女性未来育成機構が中心となり、本稿で紹 介した一連の事業の推進を通じて、教育力と研 究力に秀でた質の高い女性研究者を育成すると ともに女性研究者の働きやすい環境の整備を進 めている。今後は、本学内の取組にとどまらず、
他機関へ拡げて、大きな波及効果を狙う活動に 力を注ぎたいと計画している。 